\title{
Women Image in Elizabeth Gilbert's by Eat Pray and Love
}

\author{
Lukow Natalia Kristin, Elizabeth Z. Oroh, Delli Sabudu \\ English Education Department, Universitas Negeri Manado, Tonadno, Indonesia
}

\begin{abstract}
The purpose of this research is to reveal the women image as Seen in Gilbert's Eat Pray Love. In conducting this research, the writer uses qualitative method. In analyzing the data, the writer used mimetic approach. After conducting this research the writer arrive to the conclusion that woman image in Elizabeth Gilbert novel Eat Pray and Love describes about the modern woman image who clearly reflected through the character of Elizabeth Gilbert. Elizabeth Gilbert is a successful woman in running her carrier as a writer who finally decided to get marriage and live as a housewife but when years go by Elizabeth found herself that she does not totally enjoy with her marriage life so she decides to divorce. The discussion comes to the conclusion that Elizabeth Gilbert image as a modern woman can be mention as follow: Independent woman, Educated Woman, Strong woman and Thoughtfulness woman. Those of characteristics mention are the characteristics of woman image in the modern era where totally different than traditional woman image. Thus, there are some suggestions: 1) Woman should study to get knowledge so she can live her life as a success as she wants. 2) Independent woman does not meant uncontrolled but can control her desire to reach happiness. 3) Image of modern woman should be drive a woman into the high quality character who does not interfere by external aspect. 4) The result of this study can be a reference for other researcher who interested in analyzing about woman.
\end{abstract}

Keywords: Women Image, Novel, Character.

\section{INTRODUCTION}

Literature is technically anything spoken or writer (Roberts and Jacobs,1987, p.1) Literature is made into many form, such as drama, prose, and poetry. In literary works female figures are often discussed and are also used as imaging objects, women are interesting to talk about. A literary work which has affective nature a significant power to touch the deepest sense than can produce perfect consciousness (Wuntu, 2015: 100). Women are figures who have two sides, on the one hand women are beautiful and on the other hand women are weak, women who are often called women, daughters, wives and mothers are having the subtlety of kindness, skin, and weakness. Who have differences or composition of body shape with men. (Moenawar Chalil, 1977:8).the image of women with various negative aspects, eventually ingrained along with human history and humanity itself (Ricklander, 1993:183), according to (Effendi 2002:49) all that is seen, heard and felt as if it were going to be in real life is called imagery, based on that opinion there are many aspects that allude to images related to sensory aspects. In this study the writer attracts to study deeply one of the literary works that is novel written by Elizabeth Gilbert Eat Pray and Love. In general in the novel Eat Pray And Love, there is a lot of description about women, why women need rebellion and change in themselves and their lives, as a woman in the family, the female figure featured in the eat 
pray and love novel is a strong, optimistic woman in making life choices who want change and progress, and able to fight for what is in his interest, Image means image 'can be a picture that many people have of personal, or mental visual impressions caused by a phrase word. It is also related to the function of literary text, according to Maru stated: A literary text provides learners with real world experiences, relationships between society and people where the target language is spoken, even if they are fictions. (Maru, 2014, p.2). Images can lead to physical and unphysical forms something that is referenced and which is related to sensing and mental processes of humans. Based on the opinion above it can be concluded that the image of a woman is a picture or reflection of a particular thing or object obtained from a woman's consciousness, the image of women in this research is a mental spiritual and everyday behaviour expressed by Gilbert that shows the face and characteristics of women.

Based on the definition above of thewomen in Gilbert's Eat Pray And Love, the write is interested in analyzing the topic of "Women Image". A woman is about having the nature of being a wife, getting pregnant, giving birth or being a mother. Maru: 2014 stated that "All human beings are born of women". Women have personal freedom to determine their lives, the future etc. Elizabeth Gilbert has presented a female character in she novel that tells about herself. She told of an independent woman who played an important role in the life, who had the freedom to determine she own life,she can prove that the worldly pleasure is not a guarantee to become happy, even sometime we have to lose it all to find the true happiness, the image of a woman who is in she is a woman who is educated, independent, and able to rise from all bad situations.

According to the writer, this topic is interested to be analyzed because it can show us especially; the female figure in this novel examines the image of women depicting women who accept only the treatment of men. The novel tells the story of the lives of women who face life problems that make she learning to become adults they have their own rights to determine their future and women also have the same rights with men. This motivates women to be more independent than men so those women images are clearly presented in this novel.

\section{RESEARCH METHOD}

\section{Research Design}

In conducting this research, the writer uses qualitative method. Bodgan and Biklen (1981:28) said that, "Qualitative research is descriptive." The data will be analyzed based on descriptive research. The written result of this research contains quotation from the data to illustrate and substantiate the presentation.

Based on definition above, it is clear that the presentation or the analysis of the study will be in descriptive form.

\section{Data Collection}

In doing this research, the writer collects the data from two sources. There are primary and secondary sources. The primary source of this research is the collected from the novel Eat Pray Love. The secondary sources 
are collected from dictionary, internet, and the other sources that relevant to the topic of this research.

\section{Data Analysis}

In analyzing the data, the writer used mimetic approach. Abrams (1978:26) said that, "Mimetic orientations the explanation of arts as essentially an imitation of aspect of the universe". So, the writer can conclude that mimetic approach is an approach which imitates the action of the real world. The goal of mimetic approach is to determine how well a work of literature connects with the real world and the theory can be broadened to include approaches that deal with the spiritual and symbolic, the images that connect people of all times and cultures.

\section{ANALYSIS}

\section{Woman Image}

Woman image is a picture of the existence of women, both traditional and modern. Women are seen as being who are always subordinate to men. Traditionally women play the role of submissive, dependent and domesticity. Obedient to husband, innocent and responsible for matters relating to household. While modern image the women independent, educated, and has a critical mind. It is also said that traditional it is clear enough that women's place is in the home. However, along with the evolution women's place is no longer always in home and doing all the housework things. Women in this era also become autonomous decision makers. They now can decide the good or bad for themselves even for the other. In this part the writer will discuss about the image of women through the character of Elizabeth Gilbert.

\section{An Educated woman}

The image of women in education is described by Elizabeth Gilbert, for Gilbert who have good education and have good careers, Gilbert is a woman who can rely on independence because Gilbert is a successful and educated woman who is able to compete as a successful woman. as a woman Gilbert was able to show that a woman was able to be independent and brave to work, women must maintain their image in the eyes of the public that the status they carry is not a status made but an educated woman has personal responsibility as an educated woman (Sugihastuti, 101).Elizabeth Gilbert desire of the new knowledge is showing below:

"I wanted to explore the art of pleasure in Italy, the art of devotion in India, and Indonesia, the art of balancing the two. It was only later, after admitting this dream. That all these countries begin with latter. A fairly auspicious sign, it seemed on a voyage of self discovery" ( Gilbert,2006,p41).

Gilbert wants to try something new the characteristic of Gilbert about how she loved to learn something new show that she is an educated woman and being an educated woman, it means she is powerful as is supported by her knowledge, her knowledge also lead her to become a great write which gives her many experiences and much money.

\section{Independent}


Modern women show different images from the traditional expectation on women. Traditional woman is dependent while modern woman is independent. There are some of reasons why the modern woman independent because in the modern era woman has a chance to have an education and when they finished they can get a work so financially they will also secure.

The many reasons I didn't want to be this man's wife anymore are too personal and too sad to share here. Much of it had to do with my problems, but a good portion of our troubles were related to his issues, as well. That's only natural; there are always two figures in a marriage, after all-two votes, two opinions, two conflicting sets of decisions, desires and limitations. (21)

The above quote illustrates that Elizabeth Gilbert was treated equally in a husband and wife relationship position. She can argue or discuss with her husband without feeling that she is inferior to him. This shows that Elizabeth Gilbert was very independent both in a position as a wife and as a career woman. And her independency motivate to fulfil all the desires to pursue three aspects in three countries seem strange to one another, especially the Italian and Indian conflicts. Part of Elizabeth Gilbert wants to eat meat in Venice Italy, in Italy Elizabeth learned the art of enjoying her life, and learning Italian, and in India it was a country to study art. With the help of a local teacher, Elizabeth begin a four-month discipline in spiritual exploration discovering worldly joy is a pleasure in his life and ending in Indonesian Gilbert was meet Brazilian man Felipe.

\section{Strong}

Elizabeth Gilbert shows as a strong woman because she can go through after her unhappy marriage which finally went to divorce. "I did everything before I got a divorce, praying everyday, but I had to go away from him" (Gilbert, 275). This means that Elizabeth Gilbert has already tried hard to overcome her marriage conflict but it doesn't work so she decides to divorce from her husband.

The female figure not only lies in the beauty of a face and beauty of the body, they are required to have a strong quality of self in order to survive in the increasingly fierce competition as now formed to be more independent."imitation of somebody else life with perfection, so now I have started living my own live, imperfectand clumsy as it may look, it resembling me now thoroughly"(Gilbert,108).

(According to Ihromi 1999;135) revealed divorce, marriage is also a process which involves many aspects such as economy, emotion, social, and official recognition by the community through a law that is overworked, an emotional aspect that makes Gilbert ask for divorce in she husband she feels unhappiness cheerfulness of heart, Gilbert is a woman who has the image of a strong woman who is able to face divorce with her husband, face the destruction of the household and experience depression after divorce, she is able to rise up with an expression from within she.

"Right .You're right. I need to find out who the hell I amI can't expect to make 
another relationship work untill figure out a way to have a relationship with my self . I'm not getting any younger, it's twelve months out of my life "(Gilbert ,97)

It reflects that Gilbert already rises up and shows her strength. She tries to have the healthy relationship with reality and more comfortable with it and do not deny it, she does not limit herself to explore life because she want to find her real life .She takes it as the reason able cautionary steps not to repeat the same mistakes over and over again, statement also reflect that Gilbert needs to have time to herself for quiet time and reflection. She takes a decision to change her life to be better through three countries for traveling . it is asserted that a woman is not dependent on others. They can make a change for her life to be better by herself even without a man helps Gilbert reflects a strong woman.

\section{Thoughtfulness}

Women's behaviour which is seen as the image of women in relation to themselves has positive and negative criteria that we can see in everyday life, According to (Oemarjati, 82). "Said women's behaviour which is seen as the image of women in relation to themselves has positive and negative criteria that we can see in everyday life"

All the internal problems it faces will be a material contemplation for itself, and will experience inner conflict. women's behavior will emerge when the woman takes actions that are seen good or bad in the eyes of the community in accordance with the conditions when the woman takes action.

"This was the exact joy my own face had radiated last spring, the day I discovered that the magazine I worked for was going to send me on assignment to new Zealand ,to write an article about the search for giant squid"( Gilbert, 20)

The quotation above, Elizabeth Gilbert strongly implied that she is very ambitious to be a famous write. The statement that show a moment on how Gilbert disjoined and complete sense of self that leads her to an inability to take a decision on certain things such as what she want to be in her marriage.

"I had actively participated I n every moment of the creation in this life sowhy did I feel like none of it resembled me? Why did I feel so overwhelmed with duty. Tired of being the primary breadwinner and the housekeeper and the social coordinator and the dog walker and the wife and the soon to-be mother , and somewhere in my stolen moments a writer?" (Gilbert , 21)

Gilbert was fine with situation but after their marriage has lasted for eight years. Gilbert thinks that is not a right thing to do, the husband of Gilbert tends to do fewer responsibilities than Gilbert and he think that it is not a problem to do that kind of thing. Gilbert experience internal conflict because she have a conflict with herself who feels overwhelmed with her husband.

Women who are able to interact well usually have criteria to respect others, are humble, sympathetic, sociable, and want to 
consult. But arrogant women are not wise so this is a woman who is not able to portray her relationship with other humans properly. According to (Oemarjati 1993 : 82) as a human being, a woman's perfection has a limit. a woman always needs other humans to achieve her perfection. women will be very able to get along and interact with others. but it is not uncommon that women easily cause problems in life.

Gilbert describes a good woman who reflects the image of a woman who is able to relate well to other humans, Elizabeth does not want to be imprisoned by solitude and disappointment after divorce. in Italy he studied Italian and getting acquainted with many friends was something Elizabeth did in her life. Especially when Elizabeth could be in a family and she could enjoy it all, in the second country he visited, the condition of a far comfortable word had to be faced by Elizabeth, but she realized that her aim to India was to organize herself for a spiritual problem. And finally Elizabeth returned to meet a oracle who had predicted it. The shaman was Ketut Liyer, and unexpectedly that Elizabeth finally met with a Brazilian businessman name Felipe, they finally falling in love and Elizabeth finally find love back in Bali.

"My birthday's coming up soon if I were home, I'd be planning stupid expensive birthday party and you'd all be buying me gifts and bottles of wine. A cheaper, more lovely way to celebrate would be to make a donation to help a healer named Wayan buy a house in Indonesia" (Gilbert,2006, p277)
The quotation above is Elizabeth's letter to she friends in America, the letter was written by Elisabeth to raise funds to make Wayan and her daughter a house, the sentence was interesting in directing friends to use their money to be more meaningful. Gilbert shows someone who needs a relationship with another person in his life journey to be more meaningful. There are many things that Gilbert's journey shows the image of a woman who has relationships with other humans, whether friends around Gilbert and a fortune teller in Bali, until Gilbert can find his love again.

Gilbert's expectations for three aspects in three aspects in three Countries. Part of yourself Elizabeth wake up before dawn In Italy Gilbert studied seniors enjoying their lives, learning Italian and enjoying happiness by gaining weight. by trying various foods that many Gilbert can achieve worldly joy.

India is a country to study art, with the help of local teachers and a wise Texas Gilbert began four months full of discipline in spiritual exploration the desire to achieve worldly happiness and divinity are two of Gilbert's glory as a human being in his life, in Indonesia in the end Gilbert found the purpose of being built in a world that was balanced between joy in the world and heaven. And looking for answers on the island of Bali Gilbert became a student of a fortune teller and at a meeting with Felipe from Brazil, they liked the way beautifully.

The picture in this novel presented by Gilbert is a journey of life that can occur to anyone. a woman's image which can be described as Elizabeth is an educated 
woman, a social woman, who has a good personal personality who can make her own choices. she left all his wealth, after she a life divorce. she choose to find she identity, Gilbert want to go three countries. and Gilbert's decision that ended happily she find love.

\section{CONCLUSION}

After conducting this research the writer arrive to the conclusion that woman image in Elizabeth Gilbert novel Eat Pray and Love describes about the modern woman image who clearly reflected through the character of Elizabeth Gilbert. Elizabeth Gilbert is a successful woman in running her carrier as a writer who finally decided to get marriage and live as a housewife but when years go by Elizabeth found herself that she does not totally enjoy with her marriage life so she decides to divorce. The discussion comes to the conclusion that Elizabeth Gilbert image as a modern woman can be mention as follow: Independent woman, Educated Woman, Strong woman and Thoughtfulness woman. Those of characteristics mention are the characteristics of woman image in the modern era where totally different than traditional woman image.

\section{REFERENCES}

Abrams, M. H. 1979. The Mirror and the Lamp. Oxford: Oxford University Press. Bodgan, C.R. and Biklen S.K. 1992. Qualitative Research for Education 2nd ed. Boston: Allyn Bacon, Inc.

Berg L Bruce (2001) Qualitative Research Methods for the social and science. Long beach California state University. Elizabeth Gilbert, E. (2006). Eat Pray and Love American Novel: One Woman's
Search for Everything Across Italy, India, and Indonesia. Penguin.

Griffith, K (1986). Writing Essay About Literature. Washington DC: Harcourt Brace Javanovich, Publisher.

Hornby, A.S. (2000). Oxford Advanced Learner's Dictionary of Current English. New York: Oxford University Press.

Humm, Maggie (2002) A reader's guide to contemporary feminism literary criticism.

Maru, G. Mister. Featuring an Ideal Woman in Ibsen's Ghost. Jurnal Pendidikan Bahasa, Sastra dan Budaya. Vol. 1. No. 1. Oktober 2014.

Maru, Mister Gidion. (2014). Experimenting Jeremiadic Approach as an Alternative for TEFL in Meeting the Demand of the 2013 Curriculum.

Wuntu, C. N. (2015). Connecting the Vanishing Flora. Fauna and Its Relation to the Indian Removal Policy as Seen in Cooper's the Leather stocking Tales. Vol. 15.

January 29 (2013) http://npaphistory.wikispaces.com

January 29 (2013) http://www.merriamwebster.com/dictionary/woman

January29 (2013) http://kristimaloney.hubpages.com/hub/ Eat--Pray--Love-A-Book-Summary-andReview

January 29 (2013)http://www.anandaseva.org/yoga/ womens-role-in-the-society

Maggie hum (2000) Dictionary of theories: Woman to woman.

Mister Gidion Maru(2018) Women Stuggle in khaledHosseini's Thousand splendid suns.

(http://kristimaloney.hubpages.com/hub/Eat --Pray--Love-A-Book-Summary-andReview). 